\title{
A Statistical Analysis of Evaporative Pattern Casting Process Parameters for the Production of Aluminum Alloy Components
}

\author{
Babatunde Victor Omidiji* ${ }^{\text {(D) }}$ \\ Department of Mechanical Engineering, Obafemi Awolowo University, Ile-Ife, Nigeria \\ *e-mail: bvomidiji@gmail.com
}

\begin{abstract}
(C) 2020 Author. This is an open access publication, which can be used, distributed and reproduced in any medium
\end{abstract} according to the Creative Commons CC-BY 4.0 License requiring that the original work has been properly cited.

Received: 12 November 2019 /Accepted: 9 July 2020/ Published online: 1 August 2020

This article is published with open access at AGH University of Science and Technology Press

\begin{abstract}
Four process parameters were investigated with the aim of determining their influence on the mechanical properties of some test castings, bars, cylinders and plates. The influence was quantified in terms of percentage contribution. Analysis of variance (ANOVA), regression, main effects and interaction effects plots were employed to carry out the statistical analysis. As regards the tensile strength of the test castings, the geometry of components (GOC) dominated, contributing $90.83 \%$ and the pouring temperature (PT) contributed $91.90 \%$ influence on the hardness property. These dominating potentials of these two parameters limited the interaction of the parameters studied in the research.
\end{abstract}

\section{Keywords:}

process parameters, analysis of variance, interaction effects, test castings and mechanical properties

\section{INTRODUCTION}

The evaporative pattern casting (EPC) process was developed in 1958 [1] with a distinguishing feature of evaporative patterns made of polystyrene foam (EPS) [2-5] buried in sand moulds and never removed, as is the case with traditional sand casting methods. This makes the process different from previous methods [6]. The process is known to be very sensitive to foundry parameters and variable changes [7]. Many names have been coined and given to the process, such as replicast, lost foam, full mould and evaporative process [1] but what is important is the description "evaporative" which stands as a family name for all the trade names that have been coined so far $[8,9]$. The use of loose and green sand for the lost foam process credited to Smith Flemming in 1964 and full mould process respectively as mould materials brings to the fore the subtle difference that exists in the two forms of the evaporative process [4].

The process has some advantages over other sand casting methods such as dimensional accuracy, surface finish, sand reclamation and low cost of production [2,3]. It is believed to be environmentally friendly because the moulding material is not chemically treated [10], unlike in the other moulding methods where the moulding material is treated chemically before it is disposed after use [11]. Binders and other additives are not used. Other sand casting methods use these to bind sand grains together and improve on the properties [5]. This may have been informed by the coating applied on the surface of the patterns buried in evaporative moulds. Its disadvantages are associated with the pattern material used in the process [12].

In this work, four process parameters; pouring temperature (PT), grain fineness number (GFN), gating ratio (GR) and geometry of components (GOC) are investigated to determine their effects on the mechanical properties; tensile strength, percent elongation and the hardness of some test castings; cylinders, plates and bars. Taguchi's approach [13] to the design of experiments was employed to determine the number of experiments. This was found to be nine runs (three bars, cylinder and plates) to provide for good statistical analysis of the parameters. The coating applied on the pattern was developed from silica sand and kaolin with alcohol as the carrier.

The statistical analysis provides for the determination of the effects of the parameters on the mechanical properties. Main and interaction effects plots were made to explain these aspects. An analysis of variance tables on each of the properties are also provided. Minitab (17.0), in its trial version, was used to automatically generate the plots and tables. 


\section{MATERIALS AND METHODS}

\subsection{Materials}

The materials used in the research are presented in Table 1.

Table 1

Materials used in the research

\begin{tabular}{cccc}
\hline S/N & Material & Source & Uses \\
\hline 1 & $\begin{array}{c}\text { Pattern } \\
\text { material }\end{array}$ & $\begin{array}{c}\text { Polystyrene } \\
\text { foam (EPS) }\end{array}$ & $\begin{array}{c}\text { To make patterns } \\
\text { of bars, cylinders } \\
\text { and plates }\end{array}$ \\
\hline 2 & $\begin{array}{c}\text { Binding } \\
\text { material }\end{array}$ & Glue & $\begin{array}{c}\text { For binding the } \\
\text { patterns and } \\
\text { gating systems }\end{array}$ \\
\hline 3 & $\begin{array}{c}\text { Moulding } \\
\text { material }\end{array}$ & River sand & $\begin{array}{c}\text { To construct } \\
\text { moulds }\end{array}$ \\
\hline 4 & $\begin{array}{c}\text { Casting } \\
\text { material }\end{array}$ & Al-Si alloy & $\begin{array}{c}\text { To produce } \\
\text { the bars, cylinders } \\
\text { and plates }\end{array}$ \\
\hline & $\begin{array}{c}\text { Coating } \\
\text { material (silica } \\
\text { sand, kaolin } \\
\text { and alcohol) }\end{array}$ & $\begin{array}{c}\text { River sand, clay } \\
\text { deposit, me- } \\
\text { thyl alcohol }\end{array}$ & $\begin{array}{c}\text { To produce } \\
\text { the coating }\end{array}$ \\
\hline
\end{tabular}

\section{Pattern material}

Polystyrene material was the pattern material used in this research. It was used because it turns to gas, leaving a cavity in the mould at the point of contact with molten metal. The density value of the one employed in this research is $20 \mathrm{~kg} / \mathrm{m}^{3}$. It had a glassy, sparkling appearance and the ability to float on water. The water absorption capability is close to zero.

\section{Pattern preparation}

Simple shapes such as bars, cylinders and plates were selected for test castings. The dimensions of the patterns are as follows:

- bar: $250 \mathrm{~mm} \times 10 \mathrm{~mm} \times 10 \mathrm{~mm}$,

- cylinder: $\Phi 150 \mathrm{~mm} \times \mathrm{H} 150 \mathrm{~mm}$,

- plate: $250 \mathrm{~mm} \times 100 \mathrm{~mm} \times 10 \mathrm{~mm}$.

Patterns were prepared by machining from blocks of polystyrene foam with a pre-heated wire. This was done to ensure that the surfaces of the patterns were smooth. Afterwards, the patterns were coated with refractory material. The purpose was to separate the patterns from the moulding sand and provide refractory protection to ensure no metal penetration.

\section{Material for binding the pattern and gating system}

Glue was used for binding the pattern and gating system. The glue was lightly applied to the joints of the sprue, runner bar and ingates. The glue must not be heavily applied because of its wetness so that the joints can dry within a short time. The pattern with the gating system joined together was allowed to dry at the joints before being buried in the mould. The glue employed here is white in colour, usually used for the bonding of woods in woodwork practices.

\section{Moulding materials (green sand)}

Three moulding sand samples were collected from three different sand deposits. The samples had their grain fineness numbers (GFN) as 67, 75 and 100 respectively and the values are representations of grain distribution. The GFN values were determined by sieve analysis. The moisture contents of the moulding sand samples are 3.0\%, 3.4\% and $4.0 \%$ respectively, while the refractoriness values are $1420^{\circ} \mathrm{C}, 1380^{\circ} \mathrm{C}$ and $1350^{\circ} \mathrm{C}$ respectively. In preparing the sand, it was turned several times for thorough mixing to produce good flowability around the mould. When thoroughness was ensured in the mixing procedure, the sand was parked around the mould and rammed to bury the pattern and the gating system. However, the pouring cup was open to the outside through which the molten metal was poured.

\section{Casting material}

An aluminum alloy casting material was used. Chemical compounds present in the Al-alloy were determined by X-ray diffractometer (XRD) model 10 monochromatic CuK $\alpha$-radiation (wavelength $=1.5406 \mu \mathrm{m}$ ). The XRD of the Al-alloy is presented in Figure 1 and the elemental composition of the Al-alloy is presented in Table 2.

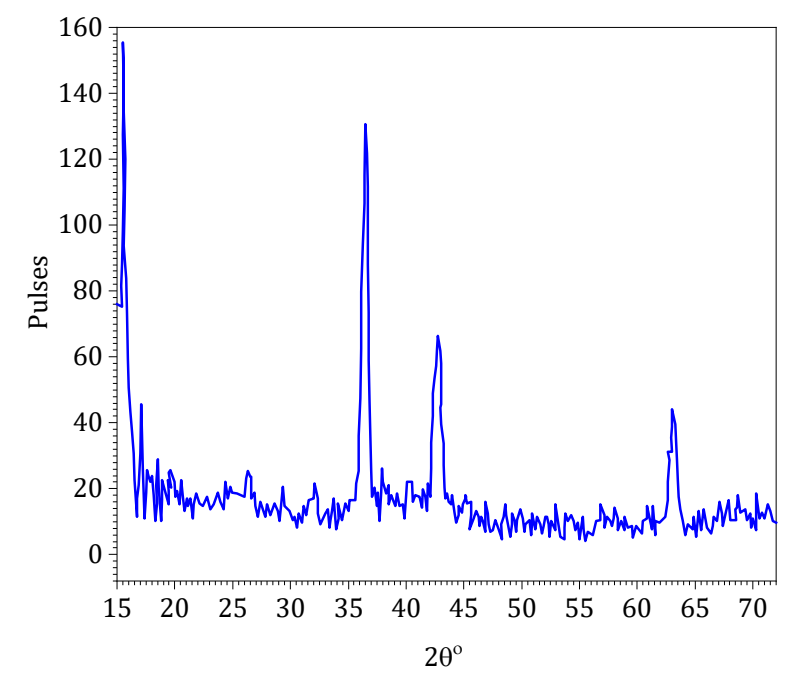

Fig. 1. XRD pattern of the Al-alloy

Table 2

Elemental composition of the Al-alloy

\begin{tabular}{ccccccc}
\hline Element & $\mathrm{Si}$ & $\mathrm{Mg}$ & $\mathrm{Fe}$ & $\mathrm{Cu}$ & $\mathrm{Mn}$ & $\mathrm{Cr}$ \\
\hline$\%$ & 1.960 & 0.310 & 0.330 & 0.580 & 0.095 & 0.015 \\
\hline Element & $\mathrm{Ni}$ & $\mathrm{Zn}$ & $\mathrm{Ti}$ & $\mathrm{Pb}$ & $\mathrm{Al}$ & \\
\cline { 1 - 5 }$\%$ & 0.026 & 0.515 & 0.020 & 0.050 & 96.100 & \\
\hline
\end{tabular}


Upon investigation of the Al-alloy using XRD, it was discovered that the alloy contained aluminum silicate $\left(\mathrm{Al}_{2}\left(\mathrm{SiO}_{4}\right) \mathrm{O}\right)$ -orthorhombic as the highest peak and the other peaks with aluminum oxide $\left(\mathrm{Al}_{2} \mathrm{O}_{3}\right)$-monoclinic and aluminum oxide-cubic. The elemental composition and XRD were done to describe the casting material.

\subsection{Methods}

\section{Mould preparation}

Evaporative pattern casting process uses one flask mould, unlike the traditional sand casting process that uses two or three. There were three sand samples of different grain fineness numbers and compositions used for the sand moulds. The sand samples were taken from three different locations of sand deposits. For each run of experiment, the sand sample was packed around the pattern as designed, using Taguchi's approach. This provides for four different process parameters to be observed in a single run of the experiment. For example, for the plate cast at $650^{\circ} \mathrm{C}$, the sand used as moulding material had GFN of 67 , the geometry was a plate and the gating ratio was 1:2:4. As the mould was prepared, a pattern with a gating system was introduced into the mould; with the gating system consisting of the down sprue, sprue base well, runners and ingates. These were determined in calculations in the design of gating system for Al-alloys. The patterns and gating system were buried in the mould by compaction of the moulding sand in the mould. The height and width of the mould for plate and bar were $110 \mathrm{~mm}$ and $350 \mathrm{~mm}$ respectively. For the cylinder, the height of the mould was $310 \mathrm{~mm}$. The projections at the sides of plate and bar castings provided for venting and flow off so that gases from the mould could escape. There were three sources of gas; molten metal, moulding material and polystyrene used as pattern material.

\section{Melting and pouring of the molten Al-alloy}

The aluminum alloy was melted in a pit furnace. Furnace fuel oil was used to fire the furnace. Alloy of about $15 \mathrm{~kg}$ was melted in the furnace each time that a bar, cylinder and plate were cast. Degassing was done when the alloy had melted, and just about to be poured into the prepared moulds. Hexachloromethane was employed in degassing at the pouring temperature.

The parameters observed and varied during the process of pouring included the following:

- pouring temperature: $650^{\circ} \mathrm{C}, 700^{\circ} \mathrm{C}$ and $750^{\circ} \mathrm{C}$,

- grain fineness of moulding sand: 67, 75 and 100,

- gating ratio: $1: 2: 4,1: 3: 3$ and $1: 4: 4$,

- geometry of components: bar, cylinder and plate.

The use of a K type (nikel-chromium) thermocouple with a grinded junction was employed to measure the temperatures. If the temperature was higher than needed, the melt was allowed to lose heat. Temperatures were taken at intervals to prevent the temperature dropping below that which was required. As soon as the desired temperature was attained, pouring was done quickly; otherwise the molten metal would solidify.

\section{Shakeout operation and fettling of the castings}

Shakeout was done after solidification of the molten metal had taken place inside the mould. Time must be given to allow solidification to take place. By using a trowel, the shakeout operation was done to carefully remove the sand packed around the pattern, gating and feeding system. After the castings were taken out of the moulds by breaking the moulds, the sand particles on the castings were removed with the use of a wire brush. This was followed by dressing, filing away the unwanted projections and the gating systems were cut off with a hacksaw. The isometric views of the test casting produced using gating ratio 1:2:4 are presented in Figures 2, 3 and 4.

\section{Mechanical properties evaluation}

Tensile test samples were taken from the castings to evaluate their mechanical properties; ultimate tensile strength (UTS), percent elongation and hardness. Instron tensile testing machine was used for the UTS and percent elongation while a microhardness tester was used to obtain the hardness values.

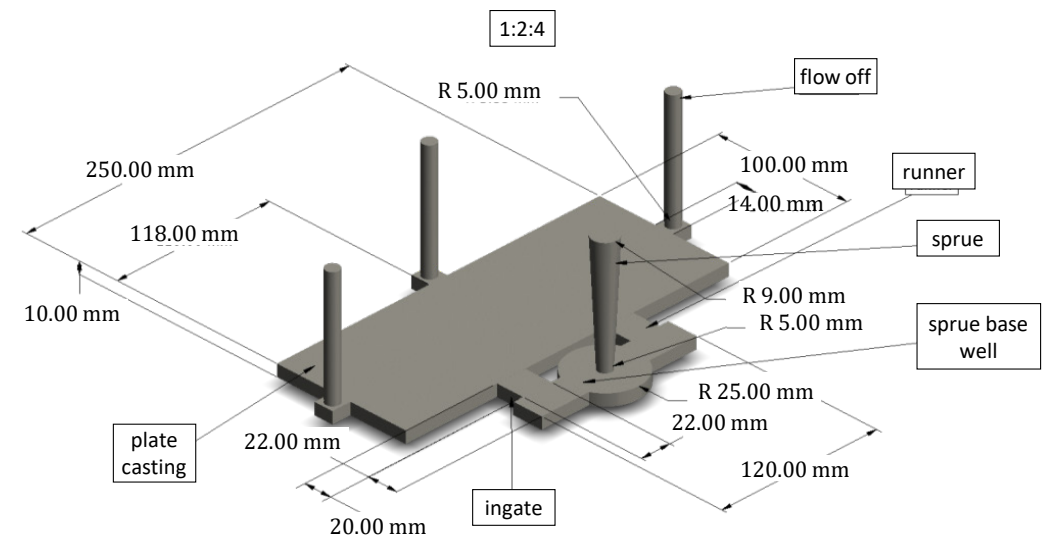

Fig. 2. An isometric view of plate casting 


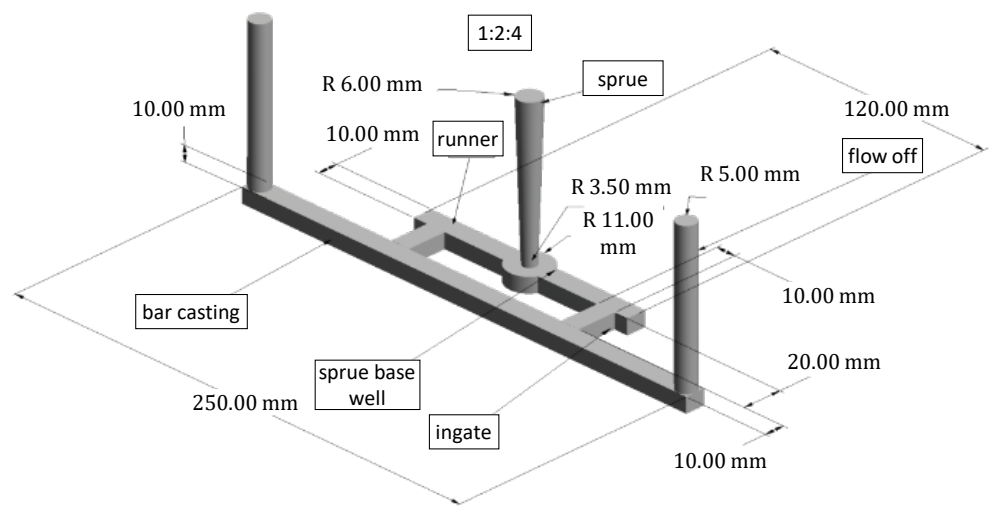

Fig. 3. Isometric view of bar casting

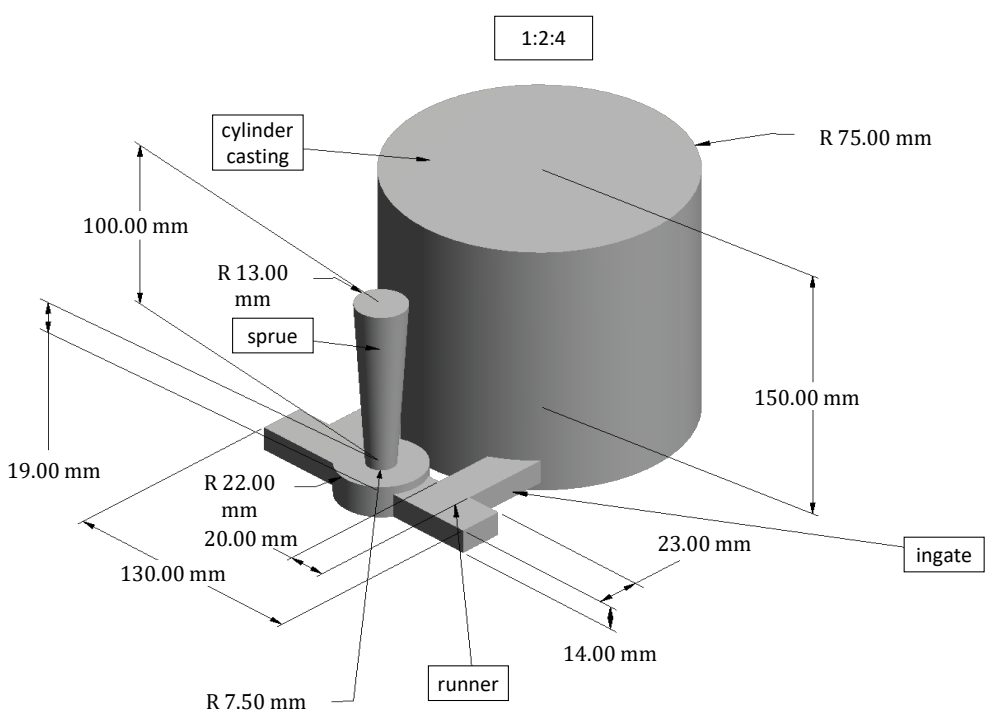

Fig. 4. Isometric view of cylinder casting

\section{Experimental design}

Using Taguchi's approach to experiment design and observing the four process parameters, nine runs of experiments were conducted. This is presented in Table 3. For each experiment, the four variables are observed at the same time.

Table 3

Taguchi's approach to design of experiments applied to EPC process

\begin{tabular}{ccccc}
\hline \multirow{2}{*}{$\begin{array}{c}\text { Runs of } \\
\text { experiments }\end{array}$} & $\begin{array}{c}\text { Pouring } \\
\text { temperature } \\
\left({ }^{\circ} \mathbf{C}\right)\end{array}$ & $\begin{array}{c}\text { Geometry } \\
\text { of com- } \\
\text { ponents }\end{array}$ & $\begin{array}{c}\text { Grain } \\
\text { fineness } \\
\text { number }\end{array}$ & $\begin{array}{c}\text { Gating } \\
\text { ratio }\end{array}$ \\
\hline 1 & 650 & Plate 1 & 67 & $1: 2: 4$ \\
\hline 2 & 650 & Bar 1 & 75 & $1: 3: 3$ \\
\hline 3 & 650 & Cylinder 1 & 100 & $1: 4: 4$ \\
\hline 4 & 700 & Plate 2 & 75 & $1: 4: 4$ \\
\hline 5 & 700 & Bar 2 & 100 & $1: 2: 4$ \\
\hline 6 & 700 & Cylinder 2 & 67 & $1: 3: 3$ \\
\hline 7 & 750 & Plate 3 & 100 & $1: 3: 3$ \\
\hline 8 & 750 & Bar 3 & 67 & $1: 4: 4$ \\
\hline 9 & 750 & Cylinder 3 & 75 & $1: 2: 4$ \\
\hline
\end{tabular}

\section{RESULTS AND DISCUSSION}

The mechanical properties in terms of the ultimate tensile strength (UTS), modulus of elasticity, percent elongation and hardness of the nine castings produced are presented in Table 4. It was observed that the results decreased with the increase in pouring temperature.

Table 4

Tensile and hardness properties values of simple shape castings

\begin{tabular}{ccccc}
\hline $\begin{array}{c}\text { Experi- } \\
\text { ments }\end{array}$ & $\begin{array}{c}\text { UTS } \\
\text { (MPa) }\end{array}$ & $\begin{array}{c}\text { Modulus of } \\
\text { elasticity } \\
\text { (MPa) }\end{array}$ & $\begin{array}{c}\text { Percent } \\
\text { elongation }\end{array}$ & $\begin{array}{c}\text { Hardness } \\
\text { (Vk) }\end{array}$ \\
\hline Bar 1 & 147.25 & 12081.79 & 3.10 & 135 \\
\hline Bar 2 & 129.88 & 11239.05 & 3.04 & 129 \\
\hline Bar 3 & 126.14 & 11178.88 & 2.44 & 121 \\
\hline Cylinder 1 & 97.53 & 15441.23 & 6.07 & 140 \\
\hline Cylinder 2 & 89.44 & 14309.85 & 3.32 & 134 \\
\hline Cylinder 3 & 85.82 & 12903.72 & 2.02 & 124 \\
\hline Plate 1 & 143.53 & 11943.77 & 5.84 & 140 \\
\hline Plate 2 & 135.58 & 11876.06 & 2.55 & 131 \\
\hline Plate 3 & 131.22 & 11700.33 & 1.75 & 122 \\
\hline
\end{tabular}


The reason adduced for this was that the structures of the castings produced with pouring temperature $650^{\circ} \mathrm{C}$ had fine grains, hence the greatest impediments to dislocations that needed to be overcome [4].

\subsection{Analysis of results}

Attempts were made to analyze the results using analysis of variance (ANOVA) for each of the properties that was measured. In the analysis, ANOVA tables, scattered, main effects and interaction plots were provided to explain the effects of the variables on the mechanical properties of the castings. Regression equations have also been provided.

\subsection{Analysis on UTS}

The ANOVA is presented in Table 5. From the table, it was observed that the geometry of components (GOC) had the largest contribution. From Table 5, it was observed that the cylinder had the lowest values of UTS. The reason may be attributed to its size, which prolonged the solidification time and leading to low values of the UTS.

Table 5

ANOVA for UTS

\begin{tabular}{cccccccc}
\hline Source & DOF & $\begin{array}{c}\text { Sum of } \\
\text { squares }\end{array}$ & & Mean of & F - & $\begin{array}{c}\text { P - } \\
\text { values }\end{array}$ & $\begin{array}{c}\text { Contribu- } \\
\text { tion (\%) }\end{array}$ \\
\hline PT $\left({ }^{\circ} \mathrm{C}\right)$ & 2 & 365.59 & 182.79 & - & - & 8.30 \\
GOC & 2 & 3999.13 & 1999.56 & - & - & 90.83 \\
GFN & 2 & 21.99 & 10.65 & - & - & 0.48 \\
GR & 2 & 16.70 & 8.35 & - & - & 0.38 \\
Error & 0 & 0.00 & - & - & - & 0.00 \\
Total & 8 & 4402.71 & - & - & - & 100.00 \\
\hline
\end{tabular}

Pouring temperature contributed $8.30 \%$ and the other two parameters were insignificant in their contributions. The regression equation for the UTS shown in Equation (1) provides a way for prediction so that UTS could be predicted when values of other process parameters are put in the Equation (1).

$$
\begin{aligned}
\mathrm{UTS} & =229.8542-0.1524 \mathrm{PT}\left({ }^{\circ} \mathrm{C}\right)+0.0979 \mathrm{GOC}- \\
& +0.0346 \mathrm{GFN}-0.0005 \mathrm{GR}
\end{aligned}
$$

where:

$$
\begin{aligned}
\text { PT - pouring temperature, } \\
\text { GOC - geometry of components, } \\
\text { GFN - grain fineness number, } \\
\text { GR - gating ratio. }
\end{aligned}
$$

The scattered plot presented in Figure 5 shows the experimental and predicted values of the UTS; the predicted values are lower than the experimental ones. From Figure 5, it was observed that the UTS values of the components bars and plates were on top while those of the cylinders were at the bottom of the plots. This shows that UTS values of plates and bars are higher than the cylinder. This explains the geometry of the test castings with respect to solidification time $[4,8]$.

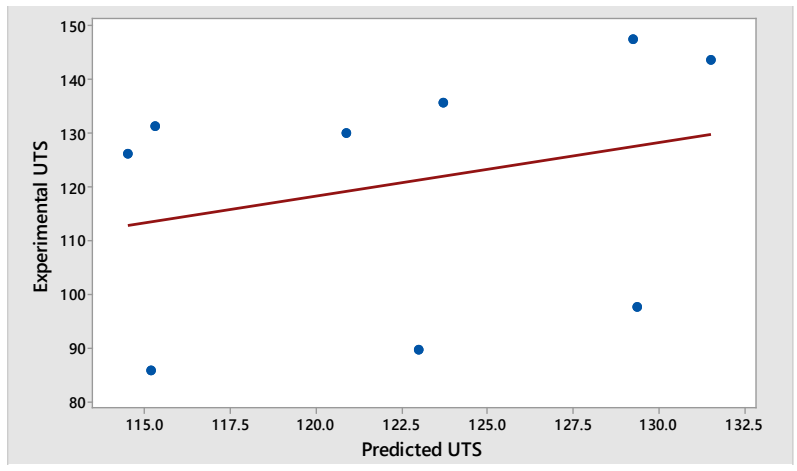

Fig. 5. Scattered plot on UTS

The main effects of the parameters on the UTS are presented in Figure 6. There are four segments in the plot, showing the variables. In each segment the variable is placed against the UTS, and reveals that pouring temperature $650^{\circ} \mathrm{C}$ produced the highest value of the UTS. The bars showed the highest strength amongst the components, attributed to its being slender and solidified on time. Its GFN 75 and gating ratio 1:3:3 produced the best ultimate tensile strength.

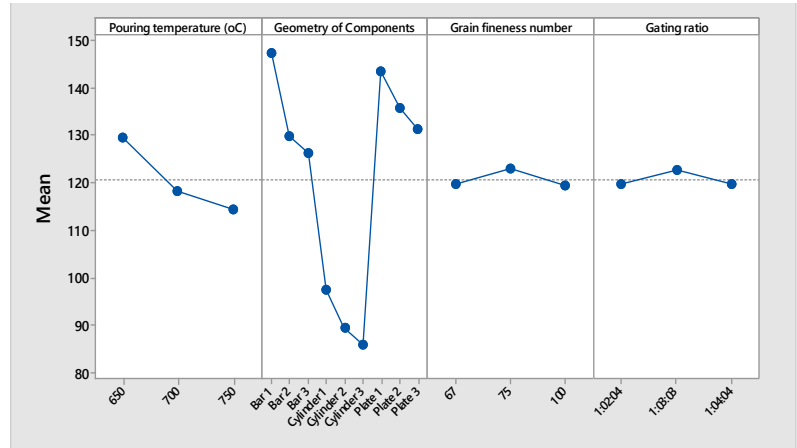

Fig. 6. Main effect of variables on UTS

The interaction effect of the variables on the UTS of the castings is presented in Figure 7. The values of the UTS obtained experimentally are placed on the $y$-axis and those quantities of the variables are on the $x$-axis. The plot is of four divisions; pouring temperature, geometry of components, grain fineness number and gating ratios. The effects of the interactions of pouring temperature and GFN, pouring temperature and gating ratio and GFN and gating ratio on UTS were investigated. From Figure 7, it was discovered that interaction between these variables were not very well pronounced. However, the plots depict the real behavior of the variables other than the main one shown in Figure 6. For example, a gating ratio of $1: 3: 3$ was shown to be predominant in Figure 6 but coming to Figure 7, in the third column and fourth row, two points were dominant while the third point was at the bottom. The plot shows that pouring temperature has an effect on the first column and row, geometry of components has effects on the second column and row, GFN has effects on the third column and row and gating ratio has effects on the fourth column and row. Looking at the interaction between the gating ratio and GFN, it is discovered that the gating ratio of $1: 3: 3$ was dominant. Next to it was the gating ratio of 1:2:4. 


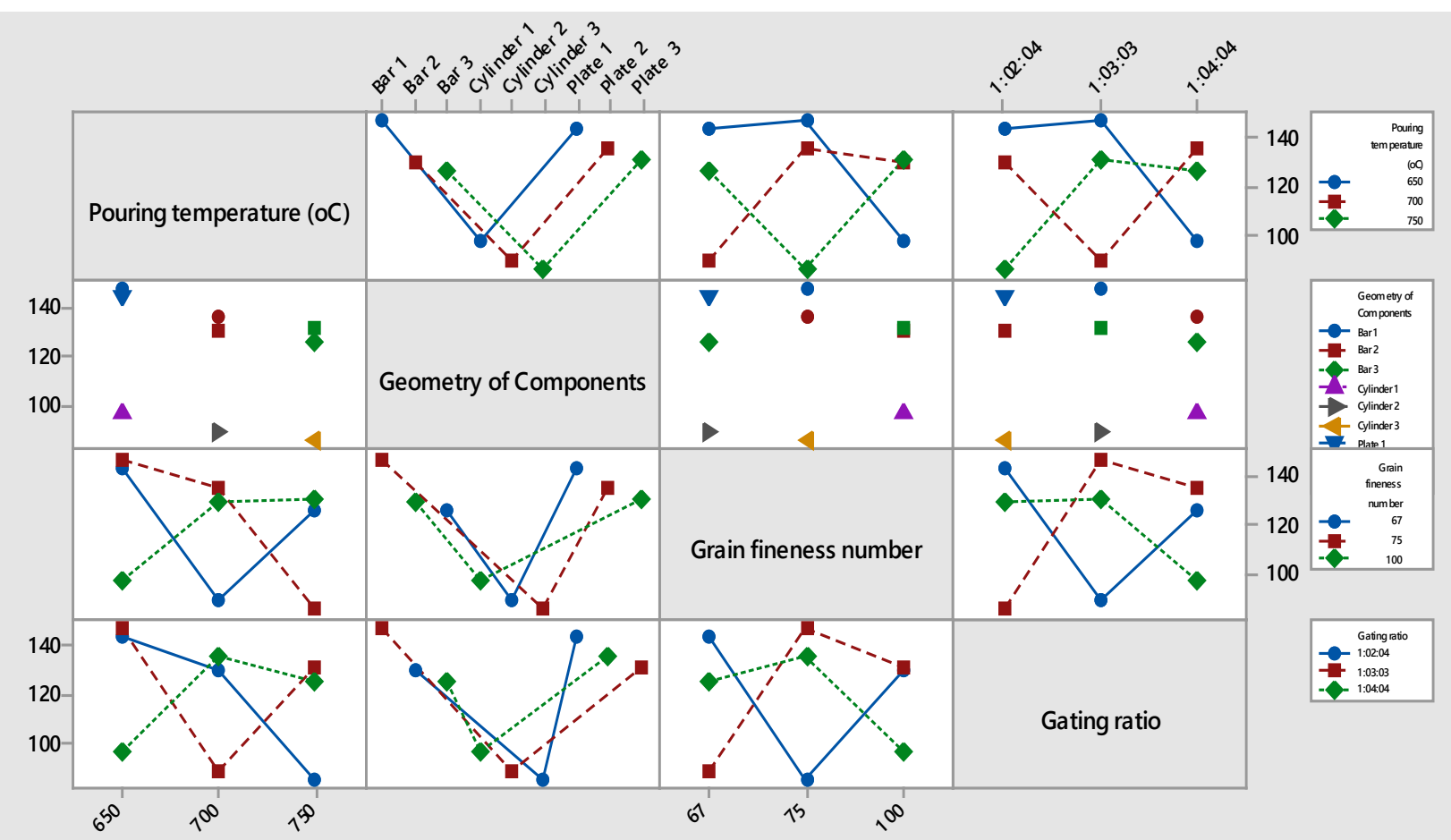

Fig. 7. Interaction effects of variables on UTS

\subsection{Analysis on hardness}

The hardness values of the test castings had been presented in Table 4 and the analysis of variance is presented in Table 6 . From Table 6, it is observed that pouring temperature played a dominant role on the hardness of the test castings, contributing 91\%. The geometry of components is about $7 \%$ contribution and the last two variables are insignificant in contribution.

Table 6

ANOVA for Hardness

\begin{tabular}{ccccccc} 
Source & DOF & $\begin{array}{c}\text { Sum of } \\
\text { squares }\end{array}$ & $\begin{array}{c}\text { Mean of } \\
\text { squares }\end{array}$ & $\begin{array}{c}\text { F }- \\
\text { values }\end{array}$ & $\begin{array}{c}\text { P - } \\
\text { values }\end{array}$ & $\begin{array}{c}\text { Contribu- } \\
\text { tion (\%) }\end{array}$ \\
\hline & & & & & & \\
PT $\left({ }^{\circ} \mathrm{C}\right)$ & 2 & 386.000 & 193.000 & - & - & 91.90 \\
GOC & 2 & 28.667 & 14.333 & - & - & 6.83 \\
GFN & 2 & 4.667 & 2.333 & - & - & 1.11 \\
GR & 2 & 0.667 & 0.333 & - & - & 0.16 \\
Error & 0 & 0.000 & - & - & - & 0.00 \\
Total & 8 & 420.000 & - & - & - & 100.00 \\
& & & & & & \\
\hline
\end{tabular}

The regression equation for the hardness of the test castings is given in Equation (2).

$$
\begin{aligned}
\text { Hardness } & =255.4449-0.1626 \mathrm{PT}\left({ }^{\circ} \mathrm{C}\right)+0.1310 \mathrm{GOC}- \\
& +0.0261 \mathrm{GFN}-0.0031 \mathrm{GR}
\end{aligned}
$$

The Equation (2) is significant in predicting what the values of hardness would be suppose the parameters are changed and different values are put into the equation. The scattered, main effect and interaction effect plots are shown in Figures 8, 9 and 10 respectively.

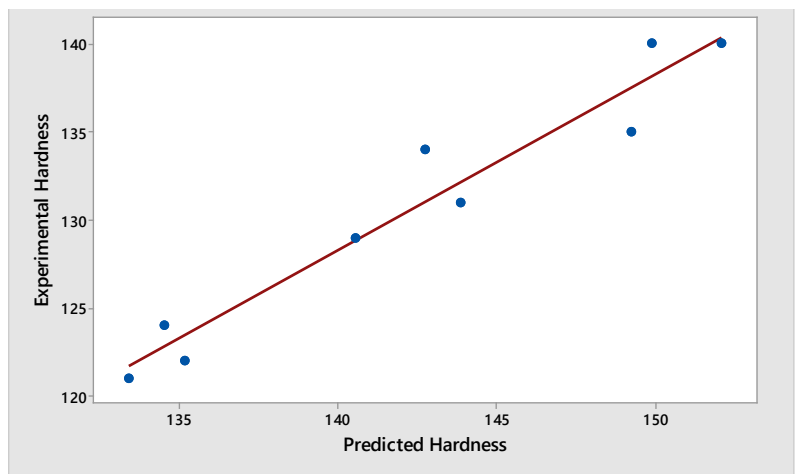

Fig. 8. Scattered plot for hardness

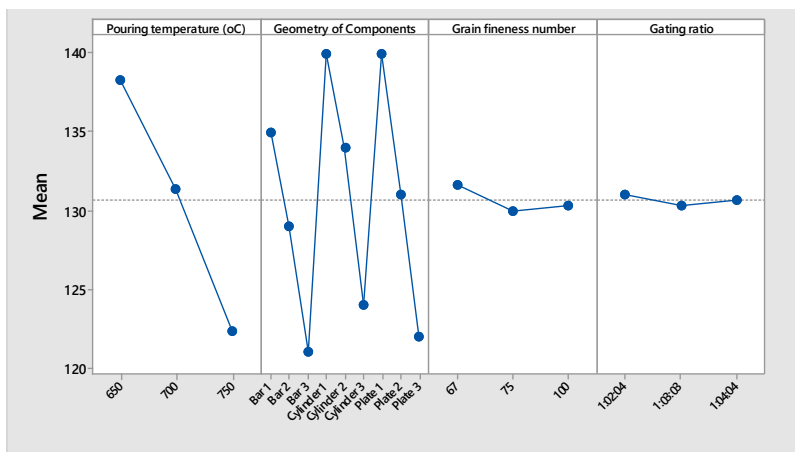

Fig. 9. Main effects for hardness

In Figure 8, the experimental and predicted values of the hardness are shown. It is observed that the predicted values are higher than the experimental ones. From Figure 9, a pouring temperature of $650^{\circ} \mathrm{C}$ produced the highest value of hardness cylinder 1 , grain fineness number of 67 and a gating ratio of 1:2:4 produced the highest value of hardness. 


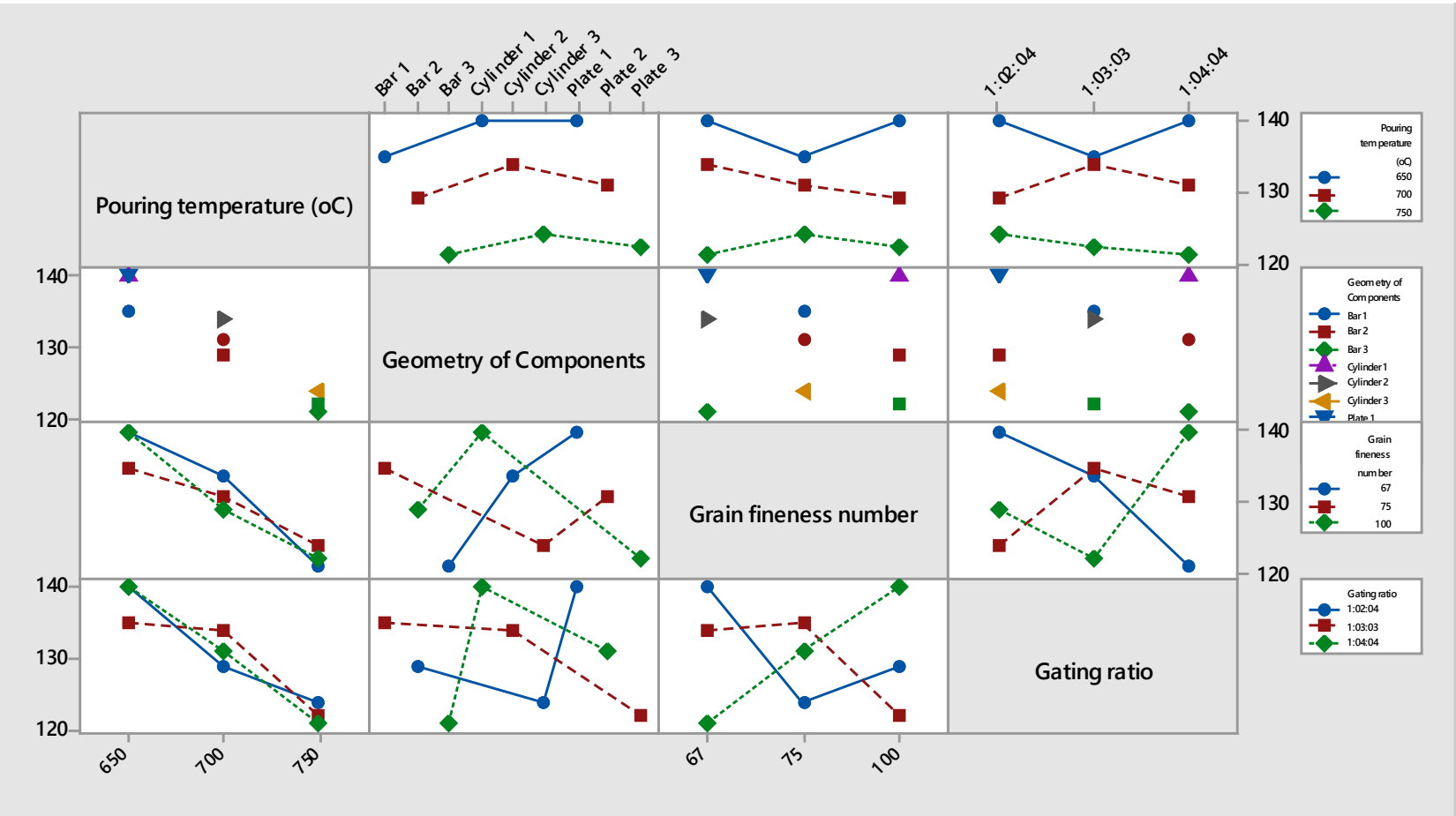

Fig. 10. Interaction effects for hardness

Figure 10 gives the interaction effects of the parameters on the hardness. The Figure is in four segments; pouring temperature, geometry of components, grain fineness number and gating ratio. From Table 6, it is observed that pouring temperature is dominant, contributing over $90 \%$ of influence, which also shows in Figure 9 where pouring temperature is dominant throughout in interaction with other process parameters.

\section{CONCLUSION}

Regression equations for the UTS and the hardness properties of the test castings, bar, cylinders and plates were formulated, which are good for prediction by substituting variable values that were not used in this research. The ANOVA showed the contribution of each of the parameters investigated. It had been observed that the dominating potential of pouring temperature in the case of the hardness values and geometry of components as regards the UTS reduced the interaction tendency of the parameters. However, the influence of each of the parameters in terms of percent contribution was shown.

\section{REFERENCES}

[1] Clegg A.J. (1991). Precision Casting Processes. Oxford (England), New York: Pergamon Press Plc.

[2] Kumar S., Kumar P. \& Shan H.S. (2006). Parametric optimization of surface roughness castings produced by Evaporative Pattern Casting Process. Materials Letters, 60, 3048-3053.
[3] Kumar S., Kumar P. \& Shan H.S. (2007). Effects of evaporative pattern casting process parameters on the surface roughness of Al-7\%Si alloy castings. Journal of Materials Processing Technology, 182, 615-623. Doi: 10.1016/j.jmatprotec.2006.09.005.

[4] Kumar S., Kumar P. \& Shan H.S. (2008). Optimization of tensile properties of evaporative pattern casting process through Taguchi's method. Journal of Materials Processing Technology, 204, 59-69. Doi: 10.1016/j.jmatprotec.2007.10.075.

[5] Kumar S., Kumar P. \& Shan H.S. (2009). Characterization of the refractory coating material used in vacuum assisted evaporative pattern casting process. Journal of Materials Processing Technology, 209, 2699-2706.

[6] Houzeaux G. \& Codina R. (2004). A finite element model for the simulation of lost foam casting. International Journal of Numerical Methods in Fluids, 46, 203-226. Doi: 10.1002/fld.757.

[7] Liu X.J., Bhavnani S.H. \& Overfelt R.A. (2007). Simulation of EPS foam decomposition in the lost foam casting process. Journal of Materials Processing Technology, 182, 333-342.

[8] Omidiji B.V. (2014). Evaporative pattern casting (EPC) process for production of Aluminum Alloy Components [Ph.D Thesis]. Federal University of Technology, Minna.

[9] Omidiji B.V. (2018). Evaporative pattern casting (EPC) process. Advanced Casting Technologies. Intechopen.

[10] Behm S.U., Gunter K.L. \& Sutherland J.W. (2003). An investigation into the effect of process parameter settings on air characteristics in the lost foam casting process. Michigan Technological University, Houghton, Michigan.

[11] Kannan P., Biernacki J.J. \& Visco D.P. (2007). A review of physical and kinetic models of thermal degradation of expanded polystyrene foam and their application to the lost foam casting process. Journal Analytical Application of Pyrolysis, 78, 162-171.

[12] Liu J., Ramsay C.W. \& Askeland D.R. (1996). A Study of Foam-Metal-Coating Interaction in the LFC Process. Transactions of the American Foundrymen's Society, 105, 419-425.

[13] Yadav N. \& Karunakar D.B. (2011). Effects of Process Parameters on Mechanical Properties of the Investment Castings Produced by Using Expandable Polystyrene Pattern. International Journal of Advances in Engineering and Technology, 1 (3), 9-18. 